\title{
The historical geological cartography: from digital archive to WebGIS environment
}

\author{
Marco Pantaloni ${ }^{\text {a,* }}$, Fabiana Console ${ }^{\mathrm{b}}$, Maria Pia Congi ${ }^{\text {a }}$, Renato Ventura ${ }^{\mathrm{a}}$ \\ ${ }^{a}$ Geological Survey of Italy, ISPRA, via V. Brancati 48, 00144 Rome, Italy \\ ${ }^{b}$ Library, ISPRA, via V. Brancati 48, 00144 Rome, Italy \\ * Corresponding author: marco.pantaloni@isprambiente.it
}

Keywords: Historical geological maps, Geological Survey, WebGIS

\begin{abstract}
:
The ISPRA Library collects and maintains the cartographic and documentary material of the Geological Survey of Italy, one of the oldest scientific institutions in the country. The collection of ancient and historical cartography on geological and geothematic themes has been collected since the second half of the 19th century and derives from the acquisitions started in 1867, following the institution of the Royal Geological Committee and the Royal Geological Survey. The Royal Geological Survey was established in 1873 with the task of the creation and publication of the geological map of Italy. Its activity was entrusted to the personnel of the Corps of Mines under the administrative control of the Chief Inspector of the Corps of Mines and the scientific direction of the Royal Geological Committee. The geological field survey started in 1877, thanks to the availability of the new topographic maps of the Italian Military Geographical Institute and the staff of geologists and engineers at the Royal Geological Survey (Pantaloni, 2016). This patrimony has been organically ordered and has been the object of a project aimed at its acquisition in digital format, in order to facilitate online access to the collection.
\end{abstract}

In fact, the collection has been studied, catalogued, indexed, acquired in digital format and archived in a specific Online Public Access Catalog (OPAC) indexed according to International Standard Bibliographic Description-Cartographic Materials (ISBD-CM) standards (ICCU, 2012). All the digital material, after the insertion of a non-invasive watermark, was uploaded to the server of the ISPRA Library, linked to the relevant catalog entry and made available for free download directly from the consultation mask of the OPAC catalog (www.opac.isprambiente.it) of the Library (Console \& Pantaloni, 2016).

The first phase of this work consisted in the selection and historical analysis of about 1500 cartographic objects, mostly pertaining to the Italian territory, some of them accompanied by manuscript reports, chosen on the basis of conservation characteristics, historical value and scientific and cultural significance (Pantaloni et alii, 2016a; 2016b; Severino et alii, 2014). The next step was the digital acquisition on a flat scanner that was performed of both the cartography and any accompanying elements (geological sections, attached documentation, etc.). This phase involved the production of raster images (jpg or tiff format) at high resolution ( $300 \mathrm{dpi}$ ) and the realization of corresponding thumb image. The cartographic material was then geo-referenced with the help of the most common open-source tools and it was prepared for publication through standard Web Map Services (WMS) and Representational State Transfer (REST) map services (Baiocchi, 2013; Cajthaml, 2011; della Maggiore et alii, 2001; IRMA, 2016).

The aim of this work was to provide a consultation and visualization service on a WebGIS integrated in the viewer of the Portal of the Geological Survey of Italy in a dedicated section (http://sgi2.isprambiente.it/viewersgi2/). The standard services, whose URLs can be found within the metadata in the online resources section, allow the user to use the information locally, together with other information layers for individual analyses and lines of research.

Therefore, in order to meet the specifications of the Spatial Data Infrastructures (SDI), which promote the sharing and efficient use of geographic information by defining metadata models at different levels, for each dataset was carried out the compilation of metadata in the National Directory of Spatial Data standard (RNDT) integrated in the catalog (http://catalogosgi.isprambiente.it/catalogosgi/) (Congi \& Pantaloni, 2018). This standard represents a set of information compliant with the better known European INSPIRE standard.

The purpose of this work is to develop an operational methodology aimed at the recovery and visualization of historical geological cartography in order to provide a valid tool for technical and scientific evaluations on the evolution of the territory. The availability of cartographic elements made in the past, and the comparison with recent reference cartography, allows to carry out qualitative evaluations on the geological-environmental modifications of the areas considered. Using appropriate analytical tools, then, it also becomes possible to attempt a semi-quantitative analysis of the geological-geomorphological variations of the territory, thus introducing the time factor into the environmental determinations. This activity has been developed on part of the historical cartographic heritage preserved at the library 
represented by 50 maps, at a factor of scale ranging from 1:25,000 to 1:500,000, homogeneously distributed on the Italian territory.

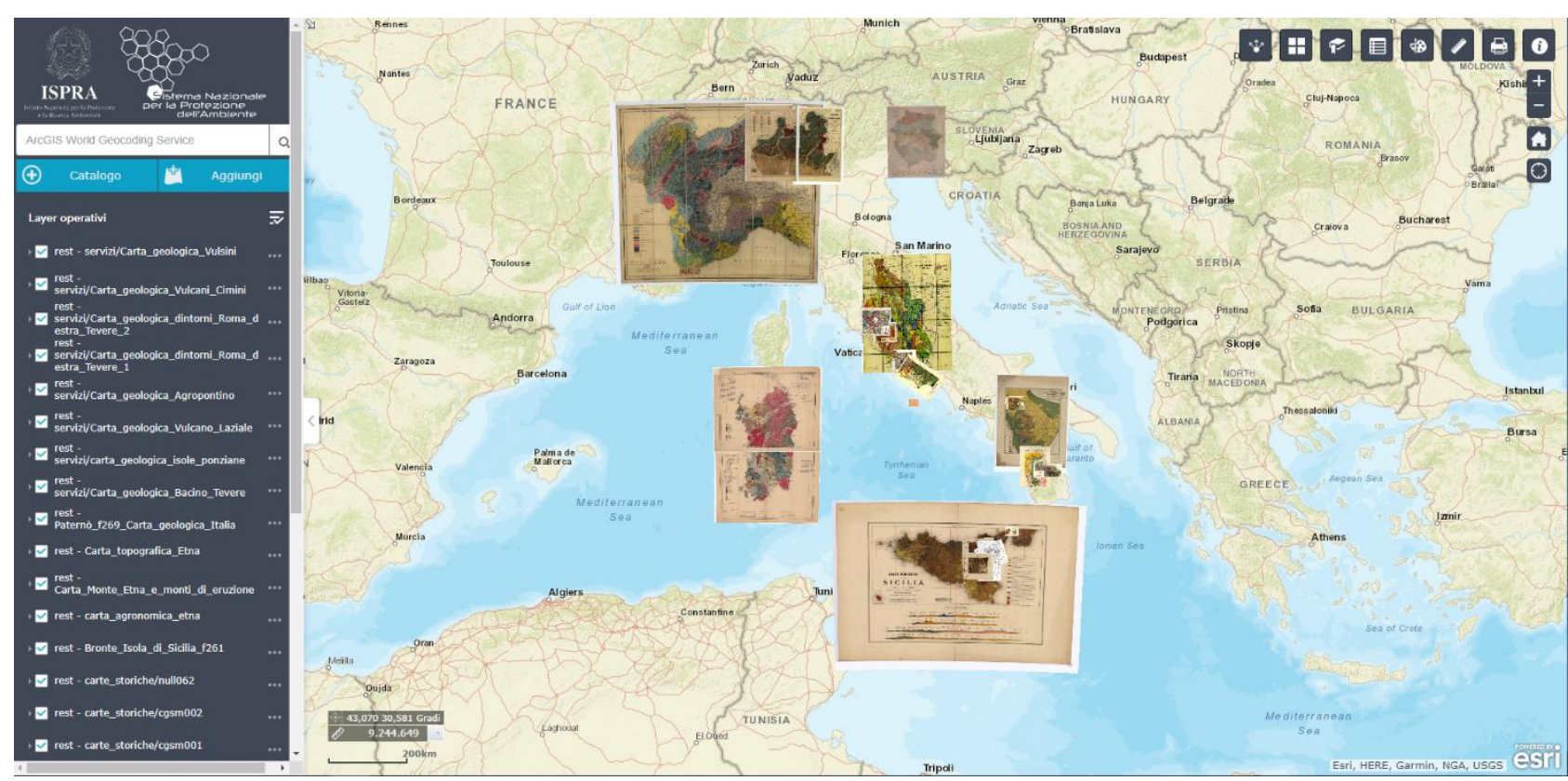

Figure 1. The historical geological maps of Piemonte, Lombardia, Friuli-Venezia Giulia, Lazio, Basilicata, Sardegna and Sicilia on the viewer of the ISPRA geoportal (http://sgi2.isprambiente.it/viewersgi2/).

The complex procedure described above, which passes through the concept of interoperability, offers the opportunity to study and deepen both the temporal phases of transformation of the territory and the evolution of technical and scientific aspects that lead to the creation of a geological map. The retrieval of the historical cartographic heritage is also a valuable aid to spread knowledge about the evolution of the territory through the use of modern communication tools that integrate the cartography that can be visualized on the web in the production of storytelling (Congi et alii, 2015; 2016).

\section{References}

Baiocchi V., Lelo K., Milone M.V., Mormile M. (2013), Accuracy of different georeferencing strategies on historical maps of Rome, Geographia Technica, 1: 10-16.

Cajthaml J. (2011), "Methods of georeferencing old maps on the example of Czech early maps", Proceedings of the 25th International Cartographic Conference, Paris, France, 3-8 July 2011.

Congi M.P., Console F., Pantaloni M., Perini P., Roma M. (2015), “La geologia di Roma (1820-2008): l'evoluzione della conoscenza geologica attraverso le mappe storiche della città", Atti della XIX Conferenza Nazionale ASITA, Lecco (Italy), settembre 2015: 277-285.

Congi M.P., Console F., Pantaloni M., Perini P., Roma M. (2016), "Raccontare la geologia attraverso le storytelling: Roma dal 1820 al 2008", GEOmedia, anno XX, n.2: 12-16.

Congi M.P., Pantaloni M. (2018), "La Direttiva INSPIRE e i dati del Servizio Geologico d'Italia: lo stato dell'arte”, XXII Conferenza Nazionale ASITA, 27-29 novembre 2018, Bolzano.

Console F. \& Pantaloni M. (2016), "La cartografia storica: dal cartaceo al digitale”, in: Console F., Pantaloni M., Tacchia D. (Eds.). Mem. Descr. Carta Geol. d'It., 100: 56-60.

della Maggiore R., Fresco R., Mura E., Perotto E. (2001), “Georeferenziazione di carte storiche”, Atti della 5a Conferenza Nazionale ASITA, Rimini, 9-12 Ottobre 2001, Vol. 1: 671-676.

Information Resources Management Association (Ed.) (2016) - Geospatial Research: Concepts, Methodologies, Tools, and Applications. IGI Global, Hershey PA, USA, 1997 pp.

Istituto centrale per il catalogo unico delle biblioteche italiane e per le informazioni bibliografiche (2012) - ISBD International Standard Bibliographic Description. Futura Grafica 70, Roma, 266 pp.

Pantaloni M. (2016) - La carta geologica d'Italia alla scala di 1:1.000.000 dal 1881 al 2011. Mem. Descr. Carta Geol. d'It., 74-78.

Pantaloni M., Console F., Petti F.M. (2016a), “1867: notizie geologiche dalle Province del Regno d'Italia”. Mem. Descr. Carta Geol. d'It., 100, 8-43.

Pantaloni, M., Galluzzo, F., Marino, M. (2016b) - Gli aspetti scientifici della Carta geologica d'Italia alla scala 1:100.000. Mem. Descr. Carta Geol. d'It., 106-121

Severino F., Console F., Pantaloni M. (2014), "Tra le carte geologiche della Biblioteca ISPRA”, Biblioteche oggi, XXXII, n. $7,49-55$. 